\title{
THE EFFECT OF LONG-TERM CROP ROTATIONS ON SOIL PROPERTIES IN SPRING BARLEY CROPS
}

Lina SKINULIENE், Department of Agroecosystems and Soil Sciences, Faculty of Agronomy, Vytautas Magnus University, Address: Studentų str. 11, LT-53361 Akademija, Kauno r., Lithuania; lina.skinuliene@ vdu.lt (corresponding author)

Lina Marija BUTKEVIČIENĖ Department of Agroecosystems and Soil Sciences, Faculty of Agronomy, Vytautas Magnus University, Address: Studentų str. 11, LT-53361 Akademija, Kauno r., Lithuania; lina.butkeviciene@vdu.lt

Vaclovas BOGUŽAS, Department of Agroecosystems and Soil Sciences, Faculty of Agronomy, Vytautas Magnus University, Address: Studentų str. 11, LT-53361 Akademija, Kauno r., Lithuania; vaclovas.boguzas@ vdu.lt

Aušra SINKEVIČIENÉ, Department of Agroecosystems and Soil Sciences, Faculty of Agronomy, Vytautas Magnus University, Address: Studentų str. 11, LT-53361 Akademija, Kauno r., Lithuania; ausra.sinkeviciene@ vdu.lt

Vaida STEPONAVIČIENĖ, Department of Agroecosystems and Soil Sciences, Faculty of Agronomy, Vytautas Magnus University, Address: Studentų str. 11, LT-53361 Akademija, Kauno r., Lithuania; vaida.steponaviciene@ @du.lt

Intensive farming and short crop rotations have encountered problems of soil degradation. Finding solutions to these problems as well as new challenges requires returning to old farming practices, adapting them to current issues. In 1965, a field experiment (crop rotation collection) was set up at the Experimental Station of Vytautas Magnus University, the significance of which not only did not decrease, but became increasingly more relevant. The object of the research is spring barley crops in cereal, Norfolk, field with row crops, intensive and for green manure crop rotations as well as continuous bare fallow. The aim of the research was to investigate the effect of long-term crop rotation combinations on soil properties in spring barley crops. Crop rotations with perennial grasses or manure fertilization have demonstrated a positive effect on soil properties. Improving the agrophysical properties also improves the biological and chemical soil properties. This tendency becomes apparent in the field experiment carried out for more than fifty years in the same place.

Keywords: crop rotation, soil $\mathrm{CO}_{2}$ emissions, soil organic carbon, shear resistance, soil structure and structural stability.

\section{INTRODUCTION}

The dynamics soil $\mathrm{CO}_{2}$ emissions are complex and variable due to both abiotic and biotic factors. $\mathrm{CO}_{2}$ formation is influenced by biochemical activities taking place inside the soil. The release of $\mathrm{CO}_{2}$ from the soil to the atmosphere is determined by a diffusion mechanism controlled by both the pore sizes of the soil and the interaction of soil moisture (Dossou-Yovo et al., 2016). Soil water retention and gas movement as well as all soil biota conditions are related to the physical soil properties (Pires et al., 2017). Changes in the physical soil properties, and with it the destruction of soil aggregates, affect microorganisms that are degraders of soil organic matter (Soane et al., 2012).

Intensive tillage and the increasing use of synthetic fertilizers have contributed to an increase in greenhouse gas (GHG) emissions, especially $\mathrm{CO}_{2}$ emissions (Lal, 2015; Liu et al., 2019; Muhammad et al., 2019; Silva et al., 2019). Tillage is one of the factors that accelerates the release of $\mathrm{CO}_{2}$ from the soil, which in turn affects the loss of soil organic carbon (Rakotovao et al., 2017). Depletion of soil carbon means physical, chemical and biological soil degradation. In this case, the soil vulnerability increases due to higher density and erosion of the resulting soil (BlancoCanqui et al., 2009). Low quantities of organic matter, as well as decreased aggregate stability and soil water retention capacity, are the reasons for the loss of microbial diversity (Zhang et al., 2010; Vezzani and Mielniczuk, 2011; Sarker et al., 2018).

Assessing such a relationship between $\mathrm{CO}_{2}$ emissions and carbon stocks requires a focus on organic carbon storage in the soil and the development of strategies to implement it (Dossou-Yovo et al., 2016).

Research hypothesis - a properly selected crop rotation has a positive effect on the physical, chemical and biological soil properties.

Research aim - to investigate the effect of long-term plant rotation combinations on soil properties in spring barley crops.

Copyright (C) 2021 The Authors. Published by Vytautas Magnus University. This is an open-access article distributed under the terms of the Creative Commons Attribution License (CC BY 4.0), which permits unrestricted use, distribution, and reproduction in any medium, provided the original author and source are credited. 


\section{RESEARCH AND METHODS}

A stationary field experiment was set up in 1965 under the initiative of Prof. Dr. A. Stancevičius at Vytautas Magnus University Experimental Station (54 $53^{\prime} \mathrm{N}+23^{\circ} 50^{\prime} \mathrm{E}$ ). The field experiment was carried out in 2018 in spring barley crops in 5 different crop rotations: intensive, field with row crops, cereal, for green manure and Norfolk as well as continuous bare fallow. Plant protection measures were applied as needed, the same tillage systems were applied for all crop rotations.

Determination of soil agrochemical properties. In each field, composite soil samples are taken from the $0-25 \mathrm{~cm}$ ploughed layer with a soil drill. Total Nitrogen is determined by the Kjeldahl method (\%) and the organic carbon content - by spectrophotometry.

Determination of soil $\mathrm{CO}_{2}$ emissions. $\mathrm{CO}_{2}$ is determined by the IRGA method (Infra Red Gas Analyzer). Portable soil respiration system LI-8100A with camera 8100-103 is used. In the spring, a $20 \mathrm{~cm}$ diameter ring with 3 measurements is hammered into each plot. Measurements are performed 3 times after sowing: at the beginning, middle and end of spring cereal vegetation.

Soil shear resistance. Soil shear resistance is determined with a Geonor 72410 shear gauge during intensive plant growth. In each field, 5 sites are measured at the ploughed depth of 10 and $25 \mathrm{~cm}$.

Determination of soil structure and structural durability. One sample of the degraded soil structure is taken from each field from a depth of 5-10 cm in the spring before sowing or during intensive growth. We use a Retsch screening machine to determine the durability of soil aggregates. A sample of 200 grams is sieved for 2 minutes, with a sieve amplitude of $30 \%$. The stability of the aggregates is determined with the Eijkelkamp wet sieving apparatus according to the Eijkelkamp methodology only from the 1-2 mm fraction sifted dry.

The data of the study year were processed by one-way analysis of variance using the computer program ANOVA from the software package SYSTAT 12. The probability of differences between all variants is determined by LSD test and applying criterion $t$ (Raudonius et al., 2009).

\section{RESULTS AND DISCUSSION}

According to the research results, the shear resistance of the soil differed when growing spring barley in different crop rotations (Table 1). The highest shear resistance at a depth of $10 \mathrm{~cm}$ was found in the Norfolk, continuous bare fallow and fodder fields and is similar to that in the intensive crop rotation fields $(\mathrm{P}>0.05)$. Significantly lower $(\mathrm{P}<0.05)$ shear resistance was found in cereal and field with row crops crop rotations compared to intensive crop rotation -22.0 and $22.8 \%$, respectively.

Table 1. Soil shear resistance in spring barley in 2018

\begin{tabular}{|l|l|l|l|l|l|l|l|}
\hline & \multicolumn{7}{|c|}{ Crop rotations } \\
\hline $\mathrm{kPa}$ & FAL & INT & CE & FWR & NOR & FOD & FGM \\
\hline $10 \mathrm{~cm}$ & $69.6 \mathrm{~b}$ & $67.5 \mathrm{~b}$ & $52.6 \mathrm{ac}$ & $52.1 \mathrm{c}$ & $69.9 \mathrm{~b}$ & $66.8 \mathrm{~b}$ & $59.6 \mathrm{ab}$ \\
\hline $25 \mathrm{~cm}$ & $67.9 \mathrm{c}$ & $67.5 \mathrm{bc}$ & $56.5 \mathrm{ab}$ & $55.7 \mathrm{a}$ & $80.7 \mathrm{~d}$ & $58.0 \mathrm{abc}$ & $59.4 \mathrm{abc}$ \\
\hline
\end{tabular}

Notes. ${ }^{a-d}$ Means followed by the same letter for the same measurement did not differ significantly $(P<0.05)$. FAL - continuous bare fallow, CE -

cereal, FWR - field with row crops, NOR - Norfolk, FOD -fodder, FGM - for green manure (after winter rape incorporation).

A similar effect of crop rotation on this physical property of the soil was found at a depth of $25 \mathrm{~cm}$. The shear resistance of barley crop soil was significantly $(\mathrm{P}<0.05), 17.5 \%$, lower in the field with row crops compared to the intensive crop rotation. The shear resistance of the Norfolk crop rotation soil was the highest and differed significantly (P $<0.05)$ from the shear resistance in the intensive crop rotation with a pre-crop of maize for spring barley. The influence of other crop rotations on the soil shear resistance of barley fields at a depth of $25 \mathrm{~cm}$ did not differ significantly.

Soil structure studies showed that the results obtained did not differ significantly in the cultivation of spring barley in different crop rotations (Table 2). No significant differences $(\mathrm{P}>0.05)$ were found within mega, macro and micro soil structure of the spring barley crop. It was influenced by spring tillage.

Table 2. Soil structure and structural stability in spring barley in 2018

\begin{tabular}{|l|l|l|l|l|l|l|l|}
\hline & \multicolumn{5}{|c|}{ Crop rotations } \\
\hline$\%$ & FAL & INT & CE & FWR & NOR & FOD \\
\hline Micro & $7.8 \mathrm{a}$ & $7.2 \mathrm{a}$ & $6.0 \mathrm{a}$ & $5.4 \mathrm{a}$ & $6.9 \mathrm{a}$ & $5.0 \mathrm{a}$ \\
\hline Macro & $62.1 \mathrm{a}$ & $50.8 \mathrm{a}$ & $45.6 \mathrm{a}$ & $47.6 \mathrm{a}$ & $52.7 \mathrm{a}$ & $50.1 \mathrm{a}$ & $50.3 \mathrm{a}$ \\
\hline Mega & $92.2 \mathrm{a}$ & $92.8 \mathrm{a}$ & $94.0 \mathrm{a}$ & $94.6 \mathrm{a}$ & $93.1 \mathrm{a}$ & $95.0 \mathrm{a}$ & $92.6 \mathrm{a}$ \\
\hline Stability & $12.7 \mathrm{a}$ & $43.7 \mathrm{bcd}$ & $31.9 \mathrm{bc}$ & $49.6 \mathrm{~d}$ & $46.1 \mathrm{~cd}$ & $58.0 \mathrm{~d}$ \\
\hline
\end{tabular}

Notes. ${ }^{a-d}$ Means followed by the same letter for the same measurement did not differ significantly (P<0.05). FAL - continiuos bare fallow, CE cereal, FWR - field with row crops, NOR - Norfolk, FOD - fodder, FGM-for green manure (after winter rape incorporation).

Researchers E. B. Dedova and G. N. Konieva (2019) found that ingestion of plant residues allows to increase the humus content by 15-18\%. Soil structure and water physical properties are improving: the structural coefficient increased from 0.81 to 1.72 and the soil density decreased from 1.32 to $1.233 \mathrm{t} / \mathrm{m}^{3}$. Significant differences between crop rotations were found during the experiment and after investigating the soil structure durability (Table 2). The highest structural 
durability was found in the fodder crop rotation field, where perennial grasses are grown for four years, and it is similar to the crop rotation field with row crops $(\mathrm{P}>0.05)$. The structure stability was significantly lower $(\mathrm{P}<0.05)$ in continuous bare fallow compared with intensive crop rotation $-70.9 \%$, cereal $-60.2 \%$, field with row crops $-74.4 \%$, Norfolk $72.5 \%$ and fodder crop rotation $-78.1 \%$.

In the spring barley crop, the first measurement ( $9^{\text {th }}$ May 2018) showed significantly higher (from 2.33 to 3.32 times) soil $\mathrm{CO}_{2}$ emissions in the field with row crops crop rotation compared to other crop rotations in which spring barley crops were grown, except for the fodder crop rotation, where no significant differences were found (Fig. 1). In the middle of crop vegetation $\left(10^{\text {th }}\right.$ July 2018 ), fodder crop rotation stood out by the intensity of soil $\mathrm{CO}_{2}$ emissions (1.39 times) compared to cereal crop rotation. In fodder crop rotation, the difference was found to be significantly higher.

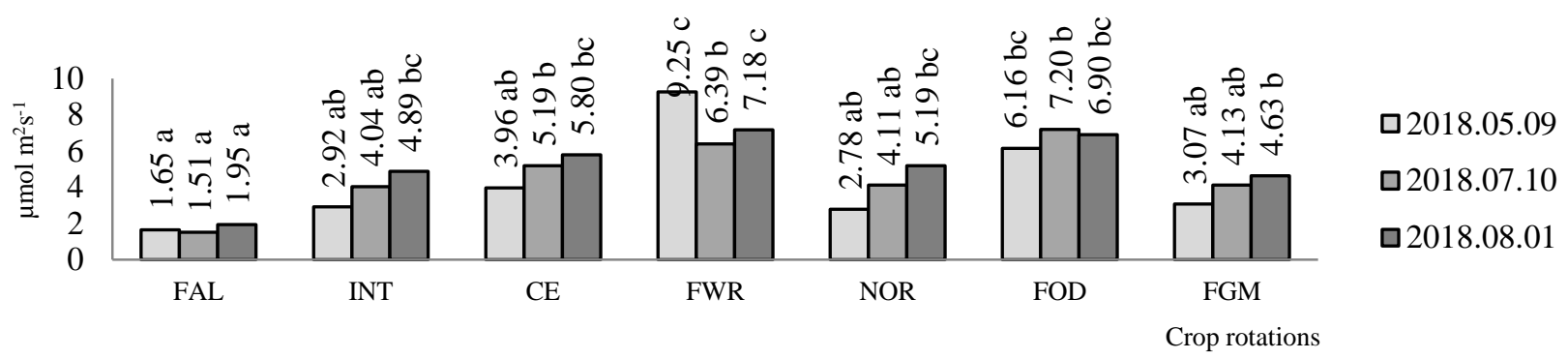

Notes. ${ }^{a-d}$ Means followed by the same letter for the same measurement did not differ significantly $(P<0.05)$. FAL - continuous bare fallow, CE cereal, FWR - field with row crops, NOR - Norfolk, FOD -fodder, FGM-for green manure (after winter rape incorporation).

Figure 1. Soil $\mathrm{CO}_{2}$ emissions in spring barley crops

After measurements at the end of the vegetation ( $1^{\text {st }}$ August 2018) significantly higher $\mathrm{CO}_{2}$ emissions (1.5 - 1.6 times) were found in the field with row crops crop rotation compared to the intensive and for green manure crop rotations.

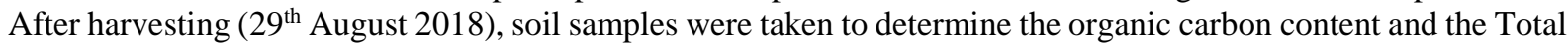
Nitrogen in the soil. Researchers Paulo et al. (2020) argue that the ideal choice of crop types in crop rotation can reduce the $\mathrm{CO}_{2}$ emissions by increasing the inputs of $\mathrm{C}$ and $\mathrm{N}$ from crop residues and $\mathrm{SOC}$ and $\mathrm{C}$ stocks, respectively. In their view, crop rotation is an important tool for achieving a positive $\mathrm{C}$ balance as well as reducing the $\mathrm{CO}_{2}$ emissions.

The highest organic carbon content was found in intensive (1.73\%), cereal and Norfolk (1.59\%) crop rotations, compared to other crop rotations (Fig. 2). The lowest (1.34\%) organic carbon content was found in the for green manure crop rotation, where the pre-crop for spring barley were potatoes, and it was significantly lower (1.29 times) compared to the intensive crop rotation.

In the intensive crop rotation, the pre-crop of spring barley is maize, and in the cereal crop rotation - oats, in the field with row crops crop rotation - sugar beet, in the Norfolk crop rotation - potatoes, in the fodder crop rotation - fodder beet.

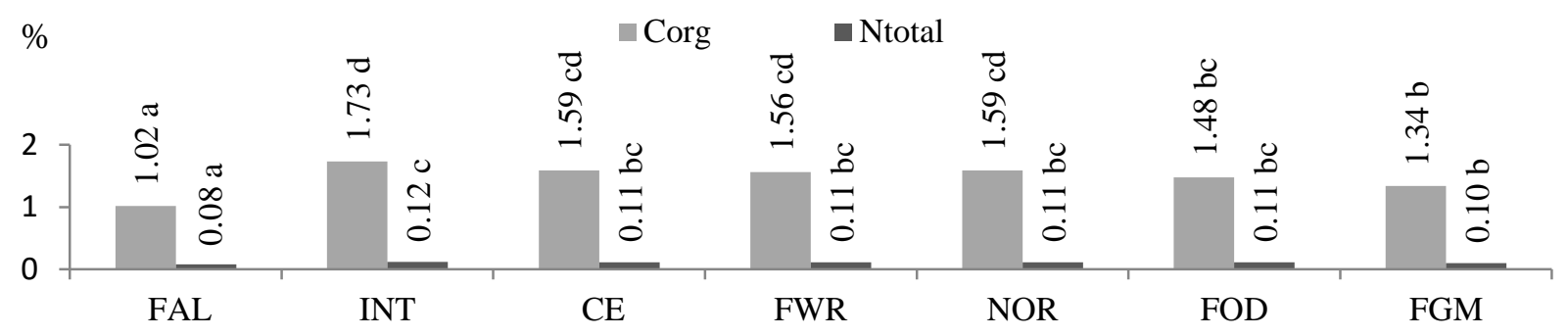

Crop rotations

Notes. ${ }^{a-d}$ Means followed by the same letter for the same measurement did not differ significantly $(P<0.05)$. FAL - continuous bare fallow, CE cereal, FWR - field with row crops, NOR - Norfolk, FOD - fodder, FGM - for green manure (after winter rape incorporation).

Figure 2. Soil $\mathrm{C}_{\text {org }}$ and $\mathrm{N}_{\text {total }}$ in spring barley crops at the depth of $0-20 \mathrm{~cm}$

When growing barley in different crop rotations, the Total Nitrogen was significantly higher (1.20 times) in the intensive crop rotation compared to other crop rotations (Fig. 2).

The lowest $(0.10 \%)$ Total Nitrogen in spring barley crop was determined in for green manure crop rotation. The highest $(0.12 \%)$ Total Nitrogen was found in the intensive crop rotation compared to other crop rotations in which spring barley crops were grown.

\section{CONCLUSIONS}

1. In spring barley crop, soil shear resistance at the depths of $10 \mathrm{~cm}$ and $25 \mathrm{~cm}$ was found to be significantly higher (P $<0.05$ ) in the Norfolk crop rotation and continuous bare fallow compared to the soil of field with row crops. 
2. Significantly lower soil structure stability $(\mathrm{P}<0.05)$ was found in the fields of continuous bare fallow, in which no plant residues were inserted compared to other combinations.

3. The lowest soil $\mathrm{CO}_{2}$ emissions were found in continuous bare fallow. Compared to bare fallow, all cereals studied showed increased soil $\mathrm{CO}_{2}$ emissions. Throughout the vegetation period of spring barley, the highest soil $\mathrm{CO}_{2}$ emissions were found in the field with row crops and fodder crop rotations.

4. The highest organic carbon content was found in spring barley crops, in intensive crop rotation with the pre-crop being maize, to which winter rye was applied as green fertilizer before sowing. The Total Nitrogen and the organic carbon content was the highest in the same crop rotation, namely: in spring barley crops - in the intensive crop rotation.

\section{REFERENCES}

1. Blanco-Canqui H., Stone L.R., Schlegel A.J., Lyon D.J., Vigil M.F., Mikha M.M., Stahlman P.W., Rice,C.W. 2009. No-till induced increase in organic carbon reduces maximum bulk density of soils. Soil Science Society of America Journa, Vol. 73, pp. 1871-1879. https://doi.org/10.2136/sssaj2008.0353

2. Dedova E. B., Konieva G. N. 2019. Agroecological Assessment of Rice Crop Rotation Soils of the Sarpinskaya Lowland. Russian Agricultural Sciences, Vol. 45, pp. 154-159. https://doi.org/10.3103/S106836741902006X

3. Dossou-Yovo E.R., Brüggemannc N., Jessed N., Huate J., Ago E.E., Agbossoub E.K. 2016. Reducing soil $\mathrm{CO}_{2}$ emission and improving upland rice yield with no-tillage, straw mulch and nitrogen fertilization in northern Benin. Soil and Tillage Research, Vol. 156, pp. 44-53. https://doi.org/10.1016/j.still.2015.10.001

4. Gonsiorkiewicz Rigon J. P., Calonego J. C. 2020. Soil carbon fluxes and balances of crop rotations under long-term no-till. Carbon Balance and Management, Vol. 15 (19), pp. 1-11. https://doi.org/10.1186/s13021-020-00154-3

5. Lal R. 2015. Soil carbon sequestration and aggregation by cover cropping. Journal of Soil and Water Conservation, Vol. 70 (6), pp. 329-339. https://doi.org/10.2489/jswc.70.6.329

6. Liu C., Yao Z., Wang K., Zheng X., Li B. 2019. Net ecosystem carbon and greenhouse gas budgets in fiber and cereal cropping systems. Science of the Total Environment, Vol. 647, pp. 895-904. https://doi.org/10.1016/j.scitotenv.2018.08.048

7. Muhammad S., Menichetti L., Kätterer T., Börjesson G. 2019. Impact of long-term N fertilization on $\mathrm{CO}_{2}$ evolution from old and young SOM pools measured during the maize cropping season. Science Total Environment, Vol. 658, pp. 1539-1548. https://doi.org/10.1016/j.scitotenv.2018.12.302

8. $\quad$ Pires L.F., Borges J.A.R., Rosa J.A., Cooper M., Heck R.J., Passoni S., Roque W.L. 2017. Soil structure changes induced by tillage systems. Soil and Tillage Research, Vol. 165, pp. 66-79. https://doi.org/10.1016/j.still.2016.07.010

9. Rakotovao N.H., Razafimbelo T.M., Rakotosamimanana S., Randrianasolo Z., Randriamalala J.R., Albrechte A. 2017. Carbon foot print of small holder farms in Central Madagascar: the integration of agroecological practices. Journal of Cleaner Production, Vol. 140 (3), pp. 1165-1175. https://doi.org/10.1016/j.jclepro.2016.10.045

10. Raudonius S., Jodaugienė D., Pupalienė R., Trečiokas K. 2009. Moksliniu tyrimu metodika. Akademija, Kauno r. pp. 119.

11. Sarker J.R., Singh B.P., Cowie A.L., Fang Y., Collins D., Dougherty W.J., Singh B.K. 2018. Carbon and nutrient mineralisation dynamics in aggregate-size classes from different tillage systems after input of canola and wheat residues. Soil Biology and Biochemistry, Vol. 116, pp. 22-38. https://doi.org/10.1016/j.soilbio.2017.09.030

12. Silva B.O., Moitinho M.R., Santos G.A.A., Teixeira D.D.B., Fernandes C., Scala N. 2019. Soil $\mathrm{CO}_{2}$ emission and short-term soil pore class distribution after tillage operations. Soil and Tillage Research, Vol. 186, pp. $224-232$. https://doi.org/10.1016/j.still.2018.10.019

13. Soane B.D., Ball B.C., Arvidsson,J., Basch G., Moreno F., Rogerestrade J. 2012. No-till in northern, western and south-western Europe: a review of problems and opportunities for crop production and the environment. Soil and Tillage Research, Vol. 118, pp. 66-87. https://doi.org/10.1016/j.still.2011.10.015

14. Vezzani F.M., Mielniczuk J. 2011. Agregação e estoque de carbono em Argissolo submetido a diferentes práticas de manejo agrícola. Revista Brasileira de Ciência do Solo, Vol. 35 (1), pp. 213-223. https://doi.org/10.1590/S0100-06832011000100020

15. Zhang N., He, X., Gao Y., Li Y., Wang H., Ma, D., Zhang R., Yang S. 2010. Pedogenic carbonate and soil dehydrogenase activity in response to soil organic matter in Artemisia ordosica community. Pedosphere, Vol. 20 (2), pp. 229-235. https://doi.org/10.1016/S1002-0160(10)60010-0 